As-Syifaa Vol 09 (02) : Hal. 112-121, Desember 2017

ISSN : 2085-4714

\title{
UJI DAYA HAMBAT EKSTRAK KAYU MANIS (Cinnamomum burmannii) TERHADAP PERTUMBUHAN Candida albicans PADA GIGI TIRUAN AKRILIK
}

\author{
Rezky Khusnul Khatima, Chusnul Chotimah, Andy Fairuz Z. Eva \\ Fakultas Kedokteran Gigi Universitas Muslim Indonesia, Makassar \\ Email : nunu.rk94@yahoo.com
}

\begin{abstract}
Background: Denture stomatitis is one of the manifestation of oral candidiasis caused by the use of denture at night, broken dentures, or denture is not kept clean. If the number of Candida albicans increase beyond the normal limit, then within a certain time Candida albicans will be attached to the denture base and will cause infections of the denture wearer in the form of denture stomatitis that could interfere with the comfort and health of the denture wearer. Cinnamomum burmannii as a natural ingredient has an effect as an anti-fungal, anti-viral, anti-bacterial, and larvasidal. Objective: To investigate the inhibition test of extracts of (Cinnamomum burmanii) on the growth of Candida albicans contained in the acrylic denture as one alternative to denture cleaning agents. Materials and Methods: This study was conducted using laboratory experimental method and using design Post test only control group design. Samples were Candida albicans taken from the denture acrylic, then test the inhibition in the Laboratory of Microbiology, Faculty of Pharmacy UMI. Results: Based on the statistical test showed that the zone of inhibition of cinnamon extract on all the different concentrations and had no significant difference in any concentration. Conclusion: Average inhibition cinnamon extract on different concentrations (20\%, 30\%, 40\% and 50\%) had no significant difference to the growth of the Candida albicans in acrylic denture, but have similar effectiveness to the inhibition of the Candida albicans. Extract of cinnamon (Cinnamomum burmannii) at concentration of $20 \%, 30 \%, 40 \%$, and $50 \%$ showed differences in inhibition is more effective than standard drugs commonly used are (Chlorhexidine 0.2\%). Inhibition of Candida albicans will increase along with the increase in the levels of concentration of extract of (Cinnamomum burmannii).
\end{abstract}

Key words: Cinnamomum burmanii, Candida albicans, Acrylic Denture, Denture stomatitis.

\section{PENDAHULUAN}

Pada tahun 2007, jumlah pengguna gigi tiruan di Indonesia mencapai $4,5 \%$ dari jumlah penduduk dan mayoritas digunakan oleh penduduk yang berusia di atas 65 tahun. ${ }^{1}$ Saat ini jenis gigi tiruan yang paling umum digunakan oleh pasien ialah gigi tiruan berbasis resin akrilik. ${ }^{2}$

Resin akrilik merupakan bahan yang hingga saat ini masih digunakan di bidang Kedokteran Gigi. Lebih dari 95\% basis gigi tiruan dibuat dari bahan resin akrilik. Resin akrilik memenuhi 
Uji daya hambat ekstrak kayu manis (Cinnamomum Burmannii) terhadap pertumbuhan Candida Albicans pada gigi tiruan akrilik

persyaratan sebagai bahan plat gigi tiruan karena tidak bersifat toksik, tidak mengiritasi jaringan, sifat fisik dan estetik baik, harga relatif murah, dapat direparasi, mudah cara manipulasi dan pembuatannya. $^{3}$

Perawatan kebersihan gigi tiruan berbasis resin akrilik sama pentingnya dengan perawatan gigi asli karena kekurangan dari resin akrilik sebagai basis gigi tiruan yaitu terdapat rongga-rongga mikro yang menjadi perlekatan sisa makanan jika tidak dijaga kebersihannya. Penumpukan sisa makanan pada gigi tiruan berbasis resin akrilik yang tidak dibersihkan dapat menyebabkan halitosis dan berdampak buruk bagi kesehatan jaringan rongga mulut, juga dapat meningkatkan jumlah mikroorganisme dalam rongga mulut seperti jamur Candida albicans. Candida albicans merupakan jamur flora normal dalam rongga mulut yang bersifat oportunistik dan dapat menjadi patogen jika lingkungan disekitarnya memungkinkan jamur ini berkembang biak menjadi lebih banyak sehingga dapat menyebabkan gangguan. ${ }^{2}$

Pencegahan infeksi oleh Candida albicans pada pemakai gigi tiruan sangat penting. Apabila jumlah Candida albicans meningkat melebihi ambang batas normal, maka dalam 113 kurun waktu tertentu Candida albicans tersebut akan menempel pada basis gigi tiruan dan akan menyebabkan infeksi pada pemakai gigi tiruan berupa denture stomatitis yang dapat mengganggu kenyamanan dan kesehatan pemakai gigi tiruan. Denture stomatitis adalah salah satu manifestasi dari kandidosis oral yang disebabkan oleh pemakaian gigi tiruan di malam hari, gigi tiruan yang rusak, ataupun gigi tiruan yang tidak terjaga kebersihannya. Denture stomatitis dapat dicegah dengan menjaga kebersihan mulut dan kebersihan gigi tiruan dari kontaminasi Candida albicans dengan merendam gigi tiruan dalam pembersih gigi tiruan pada malam hari. Bahan-bahan pembersih gigi tiruan yang ada di pasaran saat ini relatif mahal, hal ini merupakan kendala bagi pemakai gigi tiruan untuk mendapatkan bahan tersebut. Oleh sebab itu perlu adanya bahan alternatif sebagai pengganti bahan pembersih gigi tiruan. ${ }^{4}$

Di Indonesia, banyak tersedia tanaman tradisional yang bisa dimanfaatkan sebagai bahan alternatif pembersih gigi tiruan. Penggunaan tanaman obat tradisional saat ini makin meningkat seiring dengan meningkatnya harga obat dan efek samping penggunaan obat. 
Uji daya hambat ekstrak kayu manis (Cinnamomum Burmannii) terhadap pertumbuhan Candida Albicans pada gigi tiruan akrilik

Kepercayaan akan manfaat tanaman obat tradisional tersebut harus didukung dengan adanya data ilmiah. Salah satu bahan yang bisa dimanfaatkan sebagai bahan alternatif pembersih gigi tiruan yang ada di Indonesia ialah kayu manis (Cinnamomum burmannii). ${ }^{2}$

Umumnya kayu manis diolah dengan cara maserasi sehingga menjadi ekstrak kayu manis dan terbukti memiliki kandungan nutrisi dan mempunyai efek farmakologis yaitu sebagai peluruh keringat, antirematik, penambah nafsu makan, penghilang rasa sakit, antibakteri, antijamur, dll. Beberapa bahan kimia yang terkandung dalam kayu manis diantaranya minyak atsiri, eugenol, cinnamaldehyde, safrol, tannin, kalsium oksalat, dammar dan zat penyamak. ${ }^{2,5}$ Salah satu kandungan dari kayu manis tersebut dapat menghambat aktifitas dan pertumbuhan jamur, diantaranya Candida albicans. ${ }^{2}$ Selain itu, kandungan minyak atsiri kayu manis telah dimanfaatkan sebagai antiseptic. $^{6}$

Karena efek anti jamur yang dimiliki oleh tanaman kayu manis, maka dilakukan penelitian tentang uji daya hambat ekstrak kayu manis (Cinnamomum burmanii) terhadap pertumbuhan Candida albicans pada gigi tiruan akrilik yang dapat digunakan sebagai salah satu alternatif bahan pembersih gigi tiruan yang relatif murah dan mudah didapatkan.

\section{METODE PENELITIAN}

Penelitian ini merupakan jenis penelitian Eksperimental Laboratoris dengan desain penelitian Post test only group design. Penelitian ini dilakukan di Laboratorium Mikrobiologi Fakultas Farmasi UMI, pada bulan Januari 2017 - Februari 2017 dengan prosedur laboratorium yakni melakukan penelitian eksperimen dengan membiakkan Candida albicans di media yang diambil dari gigi tiruan yang terpapar oleh Candida albicans. Pada penelitian ini menggunakan ekstrak kayu manis yang diperoleh melalui ekstraksi dengan menggunakan metode maserasi setelah diperoleh ekstrak kental kayu manis (Cinnamomum burmanii), selanjutnya dilakukan pengenceran untuk membuat konsentrasi $20 \%$, $30 \%, 40 \%$, dan $50 \%$.

Uji daya hambat antijamur dilakukan menggunakan metode pengamatan zona hambat dengan melihat adanya zona bening pada sumuran yang diberi perlakuan dengan 6 kelompok, yaitu ekstrak kayu manis (Cinnamomum burmannii) 
Uji daya hambat ekstrak kayu manis (Cinnamomum Burmannii) terhadap pertumbuhan Candida Albicans pada gigi tiruan akrilik

dengan konsentrasi 20\%, 30\%, 40\%, $50 \%$, kontrol negatif yaitu dengan air/aquades dan kontrol positif dengan memberikan chlorhexidine dan diinkubasi pada inkubator selama $3 \times 24$ jam. Tujuannya untuk menentukan aktivitas mikroba yang diletakkan pada media agar yang telah ditanami mikroorganisme jamur yang akan berdifusi pada media agar tersebut.
Kemudian akan diamati zona hambat dari 6 kelompok tersebut sehingga akan diperoleh data konsentrasi ekstrak kayu manis (Cinnamomum burmanii) yang paling efektif terhadap daya hambat pertumbuhan Candida albicans pada resin akrilik. Analisis data pada penelitian ini menggunakan uji One Way Anova.

\section{HASIL PENELITIAN}

Tabel 1. Diameter rata-rata zona hambat ekstrak kayu manis (Cinnamomum burmanii) terhadap pertumbuhan jamur Candida albicans.

\begin{tabular}{ccccccc}
\hline Kelompok & $\mathrm{n}$ & Mean & SD & Median & Max & Min \\
\hline Cinnamomum burmannii 20\% & 4 & 39,30 & 2,40329 & 38,8200 & 42,31 & 37,26 \\
Cinnamomum burmannii 30\% & 4 & 40,60 & 2,95440 & 39,7050 & 44,81 & 38,19 \\
Cinnamomum burmannii 40\% & 4 & 40,71 & 1,43628 & 41,0500 & 42,06 & 38,71 \\
Cinnamomum burmannii 50\% & 4 & 42,1800 & 2,31354 & 41,7750 & 45,36 & 39,81 \\
Kontrol Positif & 4 & 18,8100 & 1,03057 & 18,8850 & 19,96 & 17,51 \\
Kontrol Negatif & 4 & 0,0000 & 0,00000 & 0,0000 & 0,00 & 0,00 \\
\hline Sumber: Data primer, 2017 & & & & & &
\end{tabular}

Tabel 2. Perbedaan diameter zona hambat ekstrak kayu manis (Cinnamomum burmanii) dengan beberapa konsentrasi yang berbeda terhadap pertumbuhan jamur Candida albicans.

\begin{tabular}{cccc}
\hline Kelompok & $\begin{array}{c}\text { Perbedaan } \\
\text { Mean }\end{array}$ & SD & $\mathrm{p}$ \\
\hline Cinnamomum burmannii $50 \%-20 \%$ & 2,87 & 1,38 & 0,340 \\
Cinnamomum burmannii 50\%-30\% & 1,57 & 1,38 & 0,858 \\
Cinnamomum burmannii 50\%-40\% & 1,46 & 1,38 & 0,892 \\
Cinnamomum burmannii 40\%-20\% & 1,41 & 1,38 & 0,904 \\
Cinnamomum burmannii 40\%-30\% & 0,11 & 1,38 & 1,000 \\
Cinnamomum burmannii 30\%-20\% & 1,30 & 1,38 & 0,931 \\
\hline
\end{tabular}

*Post hoc, One Way Anova

Sumber: Data Primer, 2017 
Uji daya hambat ekstrak kayu manis (Cinnamomum Burmannii) terhadap pertumbuhan Candida Albicans pada gigi tiruan akrilik

Tabel 3. Perbedaan diameter zona hambat Cinnamomum burmanii dengan kontrol negatif terhadap pertumbuhan Candida albicans dengan konsentrasi yang berbeda

\begin{tabular}{cccc}
\hline Kelompok & $\begin{array}{c}\text { Perbedaan } \\
\text { Mean }\end{array}$ & SD & p* \\
\hline Cinnamomum burmannii 20\%-Kontrol Negatif & 39,30 & 1,38389 & 0,000 \\
Cinnamomum burmannii 30\%- Kontrol Negatif & 40,60 & 1,38389 & 0,000 \\
Cinnamomum burmannii 40\%- Kontrol Negatif & 40,71 & 1,38389 & 0,000 \\
Cinnamomum burmannii 50\%- Kontrol Negatif & 42,18 & 1,38389 & 0,000 \\
\hline *Post hoc, One Way Anova & & & \\
Sumber: Data Primer, 2017 & & &
\end{tabular}

Tabel 4. Perbedaan diameter zona hambat Cinnamomum burmanii dengan kontrol positif terhadap pertumbuhan Candida albicans dengan konsentrasi yang berbeda.

\begin{tabular}{cccc}
\hline Kelompok & $\begin{array}{c}\text { Perbedaan } \\
\text { Mean }\end{array}$ & SD & $\mathrm{p}^{*}$ \\
\hline Kontrol Negatif-Kontrol Positif & $-18,81$ & 1,38 & 0,000 \\
Cinnamomum burmannii 20\%-Kontrol Positif & 20,49 & 1,38 & 0,000 \\
Cinnamomum burmannii 30\%-Kontrol Positif & 21,79 & 1,38 & 0,000 \\
Cinnamomum burmannii 40\%-Kontrol Positif & 21,90 & 1,38 & 0,000 \\
Cinnamomum burmannii 50\%-Kontrol Positif & 23,37 & 1,38 & 0,000 \\
\hline
\end{tabular}

*Post hoc, One Way Anova

Sumber: Data Primer, 2017

\section{PEMBAHASAN}

Berdasarkan hasil penelitian dan dilakukan pengujian dengan menggunakan uji statistik maka didapatkan diameter rata-rata zona hambat yang dari ekstrak kayu manis terhadap pertumbuhan Candida albicans. Pada uji daya hambat ekstrak kayu manis (Cinnamomum burmannii) pada konsentrasi $20 \%$,
$30 \%, 40 \%$, dan $50 \%$ terhadap daya hambat pertumbuhan Candida albicans didapatkan diameter rata-rata zona hambat terbesar yaitu pada konsentrasi ekstrak kayu manis 50\%, sedangkan diameter rata-rata zona hambat terkecil didapatkan dari konsentrasi ekstrak kayu manis $20 \%$. Hal ini sejalan dengan penelitian yang dilakukan oleh Christian Dama dkk 
Uji daya hambat ekstrak kayu manis (Cinnamomum Burmannii) terhadap pertumbuhan Candida Albicans pada gigi tiruan akrilik

pada tahun 2012 dalam hasil penelitiannya menjelaskan bahwa ekstrak kayu manis dengan konsentrasi yang berbeda memiliki zona hambat yang berbeda pula terhadap pertumbuhan Candida albicans. Komponen-komponen dalam kayu manis memiliki prosentase yang bervariasi, meskipun kayu manis masih diekstrak dari satu spesies yang sama. Faktor yang menyebabkan perbedaan yang bervariasi ini antara lain bagian kayu manis yang dijadikan bahan ekstrak, lokasi dan perbedaan waktu panen, serta perbedaan metode ekstraksi. ${ }^{2}$

Kandungan kimia yang terdapat dalam kayu manis antara lain minyak atsiri, safrole, eugenol, sinamat aldehid, tanin, damar, kalsium oksalat, dan zat penyamak. ${ }^{7}$ World Health Organization monographs on selected medicinal plants menjelaskan dalam uji eksperimental farmakologi, kayu manis memiliki efek antijamur dan antibakteri. Barnes menyatakan bahwa kayu manis memiliki efek antifungal, antiviral, antibakteri, dan larvasidal. Secara in vitro, kayu manis telah terbukti sebagai anti jamur Candida albicans Yulinah et al. menyatakan aktivitas antifungi minyak atsiri kulit batang kayu manis terhadap
Candida albicans dengan konsentrasi hambat minimum $1 \%{ }^{8}$

Komponen-komponen dalam kayu manis memiliki presentase yang bervariasi, namun secara umum, komponen terbesar dari kayu manis, serta yang paling dominan berperan sebagai agen fungitoksik adalah sinamat aldehid dan eugenol. ${ }^{2}$

Sinamat aldehid termasuk golongan aldehid aromatik yang merupakan komponen utama dalam kayu manis dan memiliki efek antifungi dan anti bakteri yang paling kuat dibanding komponen lain dalam kayu manis. ${ }^{9}$ Menurut Tampieri et al. (2005), aktivitas fungistatik ini tergantung pada lingkar aromatik atau fungsi aldehid di luar lingkar aromatik tersebut. Selain itu kemampuan sinamat aldehid dalam menghambat pertumbuhan koloni Candida albicans yang dapat mengikat enzim yang ada pada dinding sel dan juga mengikat oksigen yang dibutuhkan Candida albicans untuk metabolisme sel. ${ }^{4} \mathrm{Di}$ samping itu, sinamat aldehid juga mampu mengadakan denaturasi protein dan menurunkan tegangan permukaan sehingga permeabilitas sel bakteri dan jamur meningkat sehingga mengakibatkan kematian mikroba. ${ }^{9}$

Sinamat aldehid termasuk dalam flavonoid. Sebagai antifungi, 
Uji daya hambat ekstrak kayu manis (Cinnamomum Burmannii) terhadap pertumbuhan Candida Albicans pada gigi tiruan akrilik

flavonoid dapat menghambat pertumbuhan jamur secara in-vitro. Flavonoid menunjukkan toksisitas rendah pada mamalia, sehingga beberapa flavonoid digunakan sebagai obat bagi manusia. Sinamat aldehid yang berperan sebagai antifungi merupakan flavonoid yang mekanisme kerjanya mengganggu proses difusi makanan ke dalam sel sehingga pertumbuhan jamur Candida albicans dapat berhenti atau sampai jamur tersebut mati. $^{2}$

Komponen aktif lainnya yaitu eugenol yang merupakan golongan fenol dengan rumus kimia $\mathrm{C}^{10} \mathrm{H}^{12} \mathrm{O}^{2}$. Satu gugus $\mathrm{OH}$ fenolik bebas pada lingkar aromatiknya dan satu gugus $\mathrm{OH}$ termetilasi berperan penting dalam aktivitas eugenol dalam menghambat koloni Candida albicans. Aktifitas antifungi oleh golongan fenol juga tergantung pada besar gugusan alkil yang ditambahkan, yaitu semakin besar gugusan alkil tersebut maka aktivitas antifunginya pun semakin besar. Di samping itu, sistem kerja dari eugenol dalam agen antifungi yaitu menghambat kolonisasi Candida albicans dalam proses pembelahan sel. ${ }^{4}$

Selain itu, penelitian yang dilakukan oleh Jian Hua dan Wen Hai mendeskripsikan mekanisme antifungi oleh bahan herbal Cina, salah satunya adalah eugenol, dalam menghambat kolonisasi Candida sebagai berikut: 1). Sebelum terjadi proses pembelahan sel, terlebih dahulu terjadi proses sintesis DNA, yang di dalamnya termasuk fase $S$ (sintesis). Setelah terjadi sintesis DNA, sel akan mengalami fase $G 2$ dan fase $M$. DNA jamur. Pada jamur yang dihambat pertumbuhannya, terjadi penurunan pada proporsi fase S-G2-M. Pada hasil uji FCM (Flow Cytometri), ditunjukkan bahwa semakin besar konsentrasi agen antifungi, semakin turun proporsi fase S-G2-M, sehingga pada akhirnya juga berpengaruh pada indeks proliferasinya; 2). Sel $C$. albicans mengalami perubahan yang signifikan pada saat terpapar agen antifungi, terjadi penyusutan yang nyata pada membran selular, hilangnya organ sel, dan nukleus serta sitoplasma yang ditutupi oleh area elektron yang tebal . Berdasarkan hasil yang didapat dari FCM, di bawah pengaruh antifungi pada penelitian ini, terjadi penurunan volume sel jamur dan nukleus mengalami kerusakan; 3). Sel jamur mengalami kematian setelah terpengaruh oleh antifungi yang efektif. Hal ini ditandai dengan hilangnya transportasi membran dan integritas struktur membran. Ketika sel mati, 
Uji daya hambat ekstrak kayu manis (Cinnamomum Burmannii) terhadap pertumbuhan Candida Albicans pada gigi tiruan akrilik

kromosom DNA mengalami segmentasi, permeabilitas membran meningkat, serta konten selular dan segmen DNA menghilang. ${ }^{4}$

Berdasarkan hasil penelitian yang dilakukan dengan menggunakan uji statistik bahwa perbandingan ekstrak kayu manis (Cinnamomum burmannii) pada konsentrasi 20\%, $30 \%$, $40 \%$, dan $50 \%$ yang dibandingkan dengan kontrol positif membuktikan bahwa daya hambat ekstrak kayu manis lebih besar dibandingkan kontrol positif yang digunakan yaitu chlorhexidine. Adapun diameter zona hambat dari kontrol positif adalah 18,8 mm. Sedangkan untuk kontrol negatif tidak terdapat zona bening disekitar sumuran atau tidak menunjukan adanya zona hambat yang dihasilkan dari kontrol negatif tersebut. Hal ini menunjukan bahwa ekstrak kayu manis (Cinnamomum burmannii) dengan konsentrasi 20\% menghasilkan diameter zona hambat yang lebih besar daripada kontrol positif terhadap pertumbuhan jamur Candida albicans secara in vitro. Hal ini menunjukan bahwa ekstrak kayu manis (Cinnamomum burmannii) memiliki daya antijamur yang lebih baik daya hambatnya jika dibandingkan dengan Chlorhexidine $\quad 0,2 \%$ yang biasa digunakan sebagai antijamur dan antibiotik. Pada kontrol negatif (aquades steril) menunjukan tidak adanya diameter zona hambat yang terbentuk, sehingga dapat dikatakan bahwa kontrol negatif yang digunakan tidak memiliki daya antijamur dalam menghambat pertumbuhan jamur Candida albicans secara in vitro.

Hasil yang diperoleh dari penelitian yaitu interpretasi data statistik menunjukkan bahwa konsentrasi $20 \%$, 30\%, 40\%, dan $50 \%$ telah memperlihatkan adanya zona bening dengan diameter yang semakin meluas, dan pada konsentrasi 50\% merupakan konsentrasi yang efektif untuk digunakan dalam menghambat pertumbuhan Candida albicans. Semakin tinggi konsentrasi ekstrak kayu manis maka akan semakin besar zona bening yang akan terbentuk bahkan ekstrak kayu manis dengan konsentrasi terendah yaitu 20\% mampu melebihi kontrol positif (Chlorhexidine 0,2\%). Penelitian ini sejalan dengan penelitian-penelitian yang dilakukan sebelumnya bahwa kemampuan kayu manis dalam menghambat pertumbuhan jamur Candida albicans yaitu semakin tinggi konsentrasi ekstrak kayu manis maka besar diameter zona hambatnya. 
Uji daya hambat ekstrak kayu manis (Cinnamomum Burmannii) terhadap pertumbuhan Candida Albicans pada gigi tiruan akrilik

\section{KESIMPULAN}

Daya hambat rata-rata ekstrak kayu manis pada berbagai konsentrasi (20\%, 30\%, 40\%, dan 50\%) mempunyai perbedaan diameter ratarata yang tidak signifikan terhadap pertumbuhan jamur Candida albicans pada gigi tiruan akrilik tetapi memiliki efektifitas yang sama terhadap daya hambat jamur Candida albicans. Ekstrak kayu manis (Cinnamomum burmannii) pada konsentrasi $20 \%$, $30 \%$, 40\%, dan 50\% menunjukan adanya perbedaan daya hambat yang lebih efektif dibandingkan dengan obat standar yang biasa digunakan yaitu (Chlorhexidine 0,2\%). Daya hambat pada jamur Candida albicans akan semakin meningkat seiring dengan peningkatan kadar konsentrasi dari ekstrak kayu manis (Cinnamomum burmannii).

\section{DAFTAR PUSTAKA}

1. Aditama, Pramudya, Siti Sunarintyas, Widijono. Pengaruh Jenis dan Volumetrik Fiber Terhadap Kekuatan Transversal Reparasi Plat Resin Akrilik. Artikel Penelitian Majalah Kedokteran Gigi 2015;(1)1:103-104.

2. Dama, Christian, Standy Soelioangan, Ellen Tumewu. Pengaruh Perendaman Plat Resin Akrilik Dalam Ekstrak Kayu Manis (Cinnamomum burmanii) Terhadap
Jumlah Blastospora Candida Albicans. Manado: Universitas Sam Ratulangi. Jurnal Fakultas Kedokteran Gigi; 2013.

3. Wahyuningtyas, Endang. Pengaruh Ekstrak Graptophyllum Pictum Terhadap Pertumbuhan Candida Albicans Pada Plat Gigi Tiruan Resin Akrilik. Yogyakarta: Universitas Gadjah Mada. Indonesian Jurnal of Dentistry 2008;(15)3:187-188,190.

4. Fakhriyana, Erna, Rostiny, Sherman Salim. Efektifitas Minyak Kayu Manis Dalam Menghambat Pertumbuhan Koloni Candida Albicans Pada Resin Akrilik. Surabaya: Universitas Air Langga. Journal of Prosthodontics 2010;(1)2:19-20,22.

5. Dian, Monica. Aktivitas Antijamur Minyak Atsiri Kayu Manis (Cinnamomum zeylanicium) Terhadap Malassezia furfur In Vitro dan Pemisahannya Secara Kromotografi Lapis Tipis. Semarang: Universitas Dipenogero; 2008.

6. Gupita, Winda Citra. Perbandingan Efektifitas Minyak Atsiri Kayu Manis (Cinnamomum zeylanicum) 6,25\% Dengan Ketokenazol 2\% Secara In Vitro Terhadap Pertumbuhan Malassezia furfur Pada Pitiriasis Versikolor. Semarang: Universitas Dipenogero; 2011.

7. Hariana, Arief.. 262 Tumbuhan Obat dan Khasiatnya. Jakarta: Penebar Swadaya; 2013.151. 
Uji daya hambat ekstrak kayu manis ( Cinnamomum Burmannii) terhadap pertumbuhan Candida Albicans pada gigi tiruan akrilik

8. Pristianingrum, Niken, Soebagio, Elly Munadziroh. Uji Stabilitas Mikrobiologis Pembersih Gigi Tiruan Dengan Bahan Minyak Atsiri Kulit Batang Kayu Manis (Cinnamomum burmanii). Surabaya: Universitas Airlangga. Jurnal PDGI 2013; Vol. (62) 3:89
9. Ariwansa, Dedy. Efektifitas Ekstrak Kulit Kayu Manis (Cinnamomum burmanii) Terhadap Penurunan Kadar Volatile Sulphur Compunds (VSCs) Pada Penderita Halitosis. Makassar: Fakultas Kedokteran Gigi Universitas Hasanuddin; 2015. 19. 